\title{
One-stage Laparoscopic Nephrectomy and Ovariohysterectomy for Concurrent Dioctophymosis and Pyometra in a Bitch
}

\author{
Hellen Fialho Hartmann', Marília Teresa De Oliveira', João Pedro Scussel Feranti' \\ Gabriela Pesamosca Coradini', Bibiana Zoppas Pierezan', Bruna Copat', \\ Marco Augusto Machado Silva² \& Maurício Veloso Brun' ${ }^{1}$
}

\begin{abstract}
Background: Dioctophyme renale, also known as "giant kidney worm", is a cosmopolitan parasite, which usually affects domestic and wildlife canids in wetlands. Nephrotomy and nephrectomy are the only treatment options. Laparoscopic nephrectomy for dioctophymosis was first performed in veterinary patients in the late 90 's. Canine pyometra is one of the most frequent surgical disorder in the small animal setting. The purpose of this study was to report a case of successful one-stage laparoscopic approach for nephrectomy and ovariohysterectomy in a bitch.

Case: A female stray dog, rescued from a riverside community, was presenting hematuria. Abdominal echography revealed presence of Dioctophyme renale worms within the right renal parenchyma. Moreover, the uterus was moderately filled by anechoic content. The patient was clinically stable and undergone laparoscopy. A 10-mm trocar was established at the middle third of the right flank, followed by $12-\mathrm{mmHg} \mathrm{CO}_{2}$ insufflation. The telescope was inserted and a giant worm was seen free within the abdominal cavity. A second 10-mm port was inserted cranial and dorsally to the first one. The parasite was retrieved using a laparoscopic Kelly forceps. A third 5-mm trocar was inserted in a classic laparoscopic triangulation port positioning. Renal artery and vein were individually triple ligated using titanium clips and then transected. The right ovarian pedicle was sequentially coagulated and transected using laparoscopic bipolar forceps. The right kidney was then dissected and detached from the abdominal wall, followed by cauterization and transection of the left ovarian pedicle. The uterus was exposed out of the abdominal cavity through the 5-mm port access. Uterine body and vessels were double ligated using polyglactin 910, with transfixating ligatures, and then transected. The opening of the retrieval bag was exposed through the cranial port site incision. Eight dioctophyme worms and the kidney sections were withdrawn through the sac using a Kelly hemostat. Abdominal wounds were closed in two layers using cross-mattress polyglactin 910 sutures. Skin was closed using interrupted horizontal mattress nylon sutures. Patient was discharged on the early post-op, receiving tramadol chloride and sodium dipyrone for three days and enrofloxacin for seven days. The patient recovered uneventfully. Owner was contacted by phone eight months following surgery, which informed the bitch was clinically stable.

Discussion: Riverside stray dogs present high incidence of dioctophymosis worldwide, due to irregular feeding and consequent intake of intermediate hosts. The reported patient met those features, without previous background regarding infestation episode. It presented hematuria, which usually results from renal parenchyma consumption by the worms. The patient was retrieved nine dioctophyme worms. Laparoscopic approach for nephrectomy has already been reported in veterinary patients, as well as three-port lap-assisted OVH have been performed. Innovative aspect of this case report concerns the one-stage laparoscopic approach for both nephrectomy and OVH. Moreover, the procedures required only three-port access, which was considered a suitable and safe minimally invasive approach in dogs affected by Dioctophyme renale and concurrent indication for $\mathrm{OVH}$. The three-port access shown is adequate to perform one-stage nephrectomy and ovariohysterectomy in bitches, for reaching benefits of laparoscopic surgery in comparison to conventional approaches.
\end{abstract}

Keywords: canine, endosurgery, kidney, laparoscopy, videosurgery. 


\section{INTRODUCTION}

Laparoscopic renal resections for dioctophymosis in companion animals was first reported in the late 90's [2,4]. Dioctophymosis is most diagnosed in stray dogs [6]. Dioctophyme renale worms frequently affects the right kidney, although the giant renal worm may be found free within the abdominal cavity [1]. The biological cycle of the parasite has as intermediary hosts freshwater fish, aquatic annelids and frogs that are ingested by definitive hosts [7]. Humans can also acquire the parasite this way and beyond: through ingestion of undercooked meat. Although it is considered a zoonosis, it rarely involves humans. There is a description of this helminth in human skin and kidneys, being responsible for colic and hematuria [1]. No clinical therapy is effective in case of dioctophymosis. Nephrectomy or nephrotomy, depending on the severity of the lesion, are the only indicated treatments [10]. The purpose of this study was to report a successful caso of one-stage laparoscopic approach for nephrectomy and ovariohysterectomy in a bitch for concurrent dioctophymosis and pyometra. To the authors' knowledge, such condition was not previously reported elsewhere.

\section{CASE}

The patient, a female stray dog, rescued from a riverside community, was referred to a veterinary teaching hospital under complaint of hematuria. The patient had received parenteral synthetic progesterone four months following adoption, one month prior appointment. Abdominal echography revealed presence of Dioctophyme renale worms within the right renal parenchyma. Moreover, the uterus was moderately filled by anechoic content. The patient was clinically stable and undergone laparoscopy. Under general anesthesia, the dog was positioned in left lateral recumbency. A 11$\mathrm{mm}$ trocar was established at the middle third of the right flank, followed by $12-\mathrm{mmHg} \mathrm{CO}_{2}$ insufflation $(1.5 \mathrm{~L} / \mathrm{min}$ flow-rate). The telescope was inserted and a giant worm was seen free within the abdominal cavity. A second 11mm port was inserted cranial and dorsally to the first one. The parasite was retrieved using a laparoscopic Kelly forceps. A third 6-mm trocar was inserted in a classic laparoscopic triangulation port positioning (Figure 1).

The right kidney was raised using percutaneous stay sutures for proper hilum exposition and dissection. Renal artery and vein were individually triple ligated using titanium clips and then transected. The right ova- rian pedicle was sequentially coagulated and transected using laparoscopic bipolar forceps. The right kidney was then dissected and detached from the abdominal wall, followed by cauterization and transection of the left ovarian pedicle. The resected kidney was conditioned in a laparoscopic retrieval bag. The uterus was exposed out of the abdominal cavity through the 6-mm port access (Figure 2), following minimal incision lengthening. Uterine body and vessels were double ligated using polyglactin $910\left(\text { Shalon }^{\circledR}\right)^{1}$ 2-0 USP thread, with transfixating ligatures, and then transected.

The opening of the retrieval bag was exposed through the cranial port site incision. Eight dioctophyme worms (Figure 2B) and the kidney sections were withdrawn through the sac using a Kelly hemostat. Abdominal wounds were closed in two layers using cross-mattress 2-0 USP polyglactin 910 (Shalon $\left.^{\circledR}\right)^{1}$ sutures. Skin was closed using interrupted horizontal mattress 3-0 USP nylon (Shalon $\left.{ }^{\circledR}\right)^{1}$ sutures. Patient was discharged on the early post-op, receiving tramadol chloride (Dorless $\left.\mathrm{V}^{\circledR}\right)^{2}$ [4 $\mathrm{mg} \mathrm{kg}^{-1}$, TID] and sodium dipyrone (Dipirona gotas $\left.{ }^{\circledR}\right)^{3}\left[25 \mathrm{mg} \mathrm{kg}^{-1}\right.$, TID] for three days and enrofloxacin $\left(\text { Baytril }^{\circledR}\right)^{4}\left[5 \mathrm{mg} \mathrm{kg}^{-1}\right.$, BID)] for seven days. The patient recovered uneventfully. Owner was contacted by phone eight months following surgery, which informed the bitch was clinically stable.

\section{DISCUSSION}

Riverside stray dogs present high incidence of dioctophymosis worldwide, due to irregular feeding and consequent intake of intermediate hosts [10]. The reported patient met those features, without previous background regarding infestation episode. Dioctophyme renale affected animals are usually asymptomatic due to unilateral renal involvement. However, patients may present hematuria or dysuria, polyuria, polydipsia, anorexia and vomiting [5]. The reported bitch presented hematuria, which usually results from renal parenchyma consumption by the worms [3]. Although massively affected, no haematological or serum biochemical disturbances were found, in disagreement with other reports [5,10-12]. The patient was retrieved nine dioctophyme worms, which was considered a massive parasitism. However, others [8] have reported a case of an animal affected by 28 worms in the abdominal cavity and six in the right kidney. In this case report, there was one parasite free within the abdominal cavity, as stated by others $[5,6]$. 


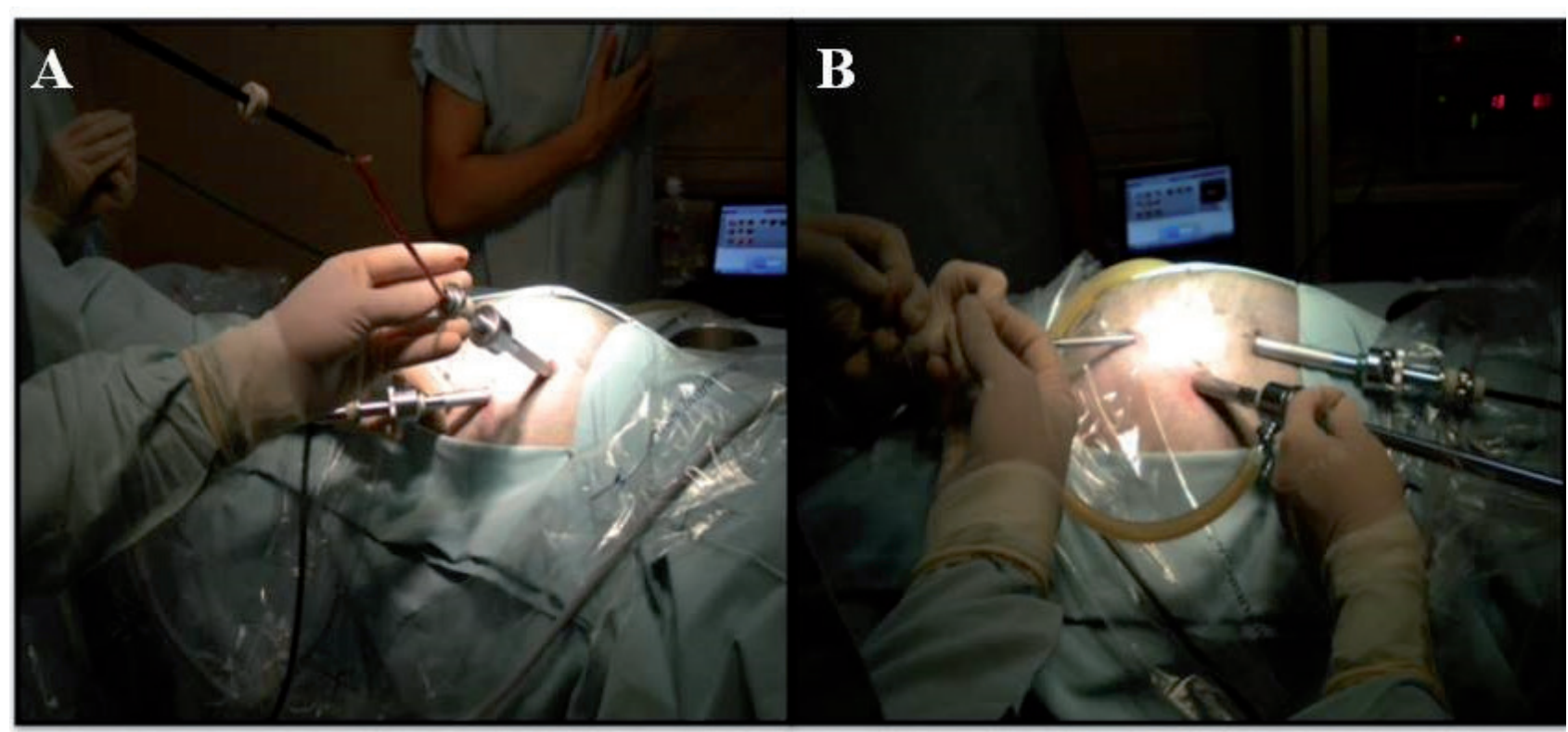

Figure 1. A- Retrieval of the parasite through the second port using a laparoscopic Kelly forceps. B- Positioning of the ports in triangulation, on the right paralumbar fossa.

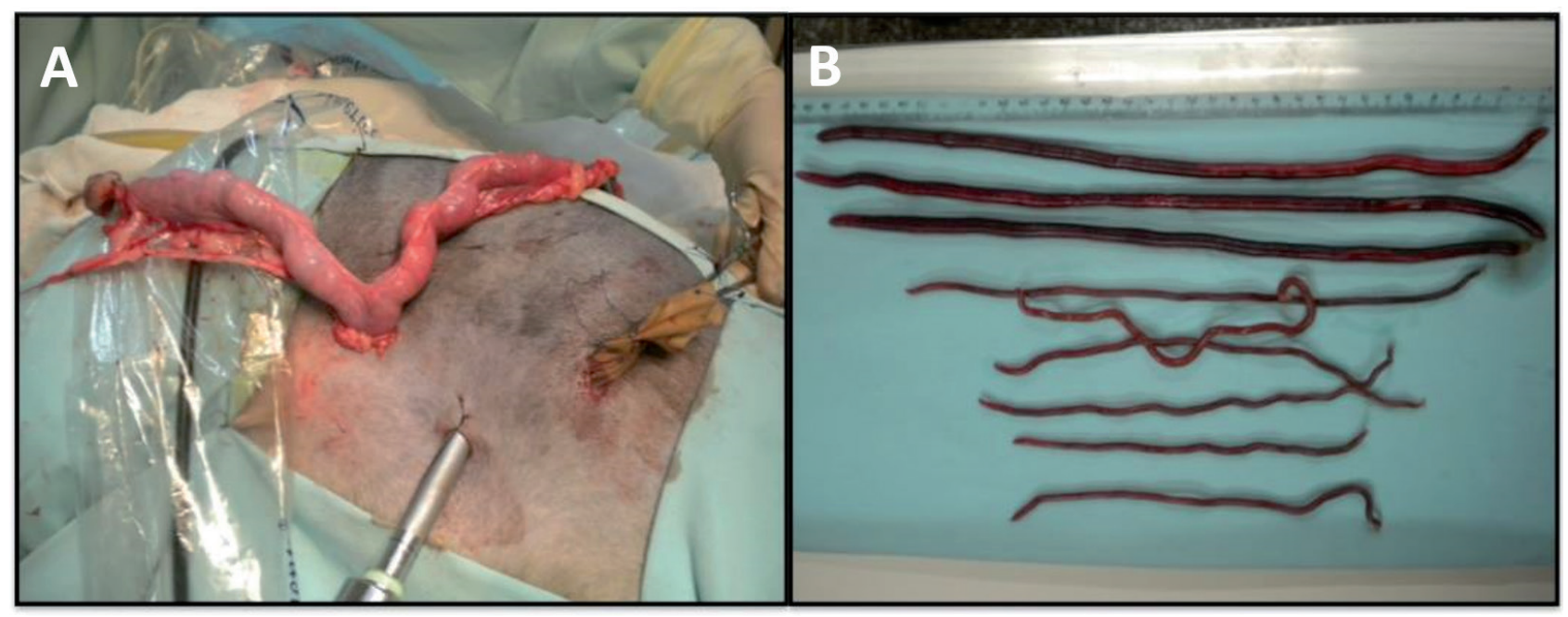

Figure 2. A- Uterus exposed through the third port incision (most caudal access). Incision required approximately 5-mm lengthening. The most cranial trocar was withdrawn with exposition of the retrieval bag opening, which contained the right kidney. B- Dioctophyma renale parasites retrieved from the right kidney (eight) and abdominal cavity (one) of a bitch, using laparoscopic approach.

Laparoscopic approach for nephrectomy has already been reported in veterinary patients $[2,4,10]$, as well as three-port lap-assisted OVH have been performed [2,9]. Innovative aspect of this case report concerns the one-stage laparoscopic approach for both nephrectomy and $\mathrm{OVH}$, using left lateral recumbency to carry out lap-assisted spay for pyometra. Moreover, the procedures required only three-port access, which was considered a suitable and safe minimally invasive approach in dogs affected by Dioctophyma renale and concurrent indication for $\mathrm{OVH}$.

In conclusion, the three-port access shown is adequate to perform one-stage nephrectomy and ovariohysterectomy in bitches, for reaching benefits of laparoscopic surgery in comparison to conventional approaches.

\section{MANUFACTURERS}

${ }^{1}$ Shalon Fios Cirúrgicos Ltda. Goiânia, GO, Brazil.

${ }^{2}$ Agener União Saúde Animal. São Paulo, SP, Brazil.

${ }^{3}$ Laboratório Biovet. Vargem Grande Paulista, SP, Brazil.

${ }^{4}$ Bayer Saúde Animal. São Paulo, SP, Brazil.

Funding. This research was supported by grants from National Counsil for Cientific and Technological Development (CNPq; 308019/2015-6 and 200346/2017-2)

Declaration of interest. The authors report no conflicts of interest. The authors alone are responsible for the content and writing of the paper. 


\section{REFERENCES}

1 Alves G.C., Silva D.T. \& Neves M.F. 2007. Dioctophyma renale: O parasita gigante do rim. Revista Científica Eletrônica de Medicina Veterinária. IV(8): 1-5

2 Brun M.V., Pippi N.L., Beck C.A.C., Mariano M.B., Oliveira S.T., Leme M.C., Stedile R. \& Braga F. 2000. Nefrectomia laparoscópica para terapêutica de dioctofimose em cães. Ciência Animal Brasileira. 1: 175.

3 Costa P.R.S., Argolo Neto N.M. \& Oliveira D.M.C. 2004. Dioctofimose e leptospirose em um cão - relato de caso. Revista Clínica Veterinária. 51: 48-50.

4 Feranti J.P.S., Motta A.C., Oliveira M.T., Wiecheteck F., Corrêa L.F.D., Pires J.S., Beck C.A.C. \& Brun M.V. 2014. Nefrectomia videolaparoscópica em Graxaim-do-campo (Pseudalopex gymnocercus) com displasia renal. Pesquisa Veterinária Brasileira. 34: 776-779.

5 Kano F.S., Shimada M.T., Suzuki S.N., Osaki S.C., Menarim B.C., Ruthes F.R.V. \& Laidane Filho M.A. 2003. Ocorrência da dioctofimose em dois cães no município de Guarapuava-PR. Semina Ciências Agrárias. 24: 177-180.

6 Kommers G.D., Ilha M.R.S. \& Barros C.S.L. 1999. Dioctofimose em cães: 16 casos. Ciência Rural. 29: 517-522.

7 Leite L.C., Círio S.M., Diniz J.M.F., Luz E., Navarro-Silva M.A., Silva A.W.C, Leite S.C., Zadorosnei A.C., Musiat K.C., Veronesi E.M. \& Pereira C.C. 2005. Lesões anatomopatológicas presentes na infecção por Dioctophyma renale (GOEZE, 1782) em cães domésticos (Canis familiaris, LINNAEUS, 1758). Archives of Veterinary Science. 10(1): 95-101.

8 Monteiro S.G., Sallis E.S.V. \& Stainki D.L. 2002. Infecção natural por trinta e quatro helmintos da espécie Dioctophyma renale (GOEZE, 1782) em um cão. Revista da FZVA. 9: 95-99.

9 Schiochet F., Beck C.A.C., Pinto R., Stedile R., Contesini E., Alievi M.M., Yamazaki P.H., Jurinitz D.F. \& Bernardes S.B.L. 2007. Ovariohisterectomia laparoscópica em uma gata com fetos mumificados - relato de caso. Revista Portuguesa de Ciências Veterinárias. 102: 361-364.

10 Secchi P., Valle S.F., Brun M.V., Motta A.C., Rausch S.F., Messina S.A. \& Vieira M.I.B. 2010. Nefrectomia videolaparoscópica para tratamento da dioctofimose em um cão. Acta Scientiae Veterinariae. 38(1): 85-89.

11 Soler M., Cardoso L., Teixeira M. \& Agut A. 2008. Imaging diagnosis - Dioctophyma renale in a dog. Veterinary Radiology \& Ultrasound. 49: 307-308.

12 Sousa A.A.R., Sousa A.A.S., Coelho M.C.O.C., Quessada A.M., Freitas M.V.M. \& Moraes R.F.N. 2011. Dioctofimose em cães. Acta Scientiae Veterinariae. 39(3): 985. 